\title{
Commentary: Should we rely on receiver operating characteristic curves? From submarines to medical tests, the answer is a definite maybe!
}

\author{
Victor A. Ferraris, MD, PhD \\ From the Department of Surgery, University of Kentucky, Lexington, Ky. \\ Disclosures: Author has nothing to disclose with regard to commercial support. \\ Received for publication Oct 20, 2018; accepted for publication Oct 21, 2018; available ahead of print Nov 30, \\ 2018. \\ Address for reprints: Victor A. Ferraris, MD, PhD, Tyler Gill Professor of Surgery, University of Kentucky, A301 \\ Kentucky Clinic, 740 S Limestone, Lexington, KY 40536-0284 (E-mail: ferraris@uky.edu). \\ J Thorac Cardiovasc Surg 2019;157:2354-5 \\ $0022-5223 / \$ 36.00$ \\ Copyright (c) 2018 by The American Association for Thoracic Surgery \\ https://doi.org/10.1016/j.jtcvs.2018.10.100
}

The article in this issue of the Journal by Ortega-Loubon and coauthors ${ }^{1}$ describes their experience with measuring oxygen saturation $\left(\mathrm{SO}_{2}\right)$ in the kidney $\left(\mathrm{kSO}_{2}\right)$ during and after cardiac operations. They used the Kidney Disease: Improving Global Outcomes (KDIGO) classification to define acute kidney injury (AKI) after cardiac operations in 121 patients. They correlated the presence of AKI with values of brain $\mathrm{So}_{2}$ and $\mathrm{kSO}_{2}$ during cardiac operations and for 48 hours after the procedures. They created receiver operating characteristic (ROC) curves to assess the predictive adequacies of $\mathrm{kSO}_{2}$ and of a $20 \%$ decrease of baseline creatinine as adequate predictors of AKI. The ROC curves in study patients were based on absolute levels of $\mathrm{kSO}_{2}$ and on a $20 \%$ decline in baseline in serum creatinine values. Ortega-Loubon and coauthors ${ }^{1}$ found that the area under the ROC curve (AUC) for $\mathrm{kSO}_{2}$ showed this value to be a modest predictor of AKI (AUC $=0.68$ ), as was a greater than $20 \%$ decline in the serum creatinine $(\mathrm{AUC}=0.63)$.

The use of KDIGO classification to define AKI makes AKI a dichotomous variable. KDIGO defines AKI as any of the following: (1) an increase in serum creatinine by $0.3 \mathrm{mg} / \mathrm{dL}$ or more within 48 hours of operation; (2) an increase in serum creatinine to greater than 1.5 times baseline; or (3) urine output less than $0.5 \mathrm{~mL} / \mathrm{kg} / \mathrm{h}$ for 6 hours. Although this characterization of renal disfunction as a dichotomous variable greatly simplifies the ability to define possible variable (like $\mathrm{kSO}_{2}$ ) correlations with $\mathrm{AKI}$, the KDIGO definition is clearly an oversimplification. This simplification undoubtedly obscures a broader set of variables that both are responsible for AKI and can be possible points of intervention for reducing AKI risk. Without much supporting evidence, Ortega-Loubon and coauthors ${ }^{1}$ suggest that measurement of $\mathrm{kSO}_{2}$ is a potentially actionable measurement that may allow interventions to reduce risks of AKI in cardiac surgical patients. Their conclusions ascribe important significance to their ROC curves that needs to be vetted.

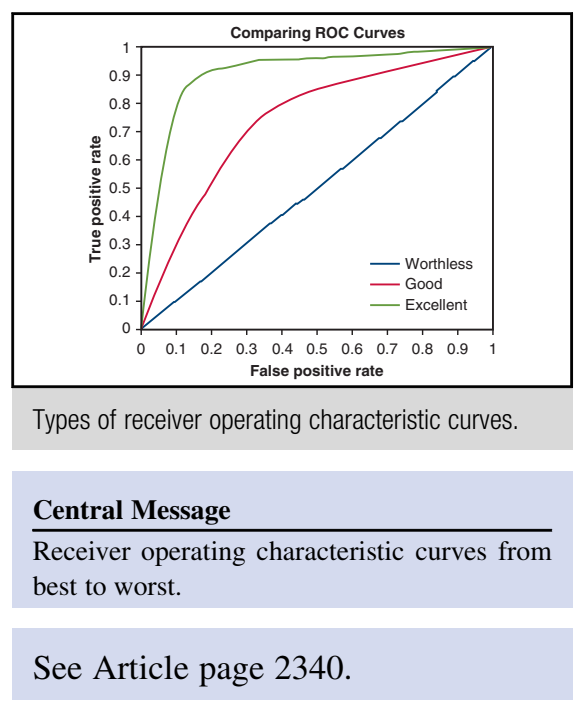

A test's ROC curve demonstrates several things: (1) It shows the trade-off between sensitivity and specificity (any increase in sensitivity will be accompanied by a decrease in specificity). (2) The closer the curve follows the left-hand border and then the top border of the ROC curve, the more accurate the test. (3) The closer the curve comes to the $45^{\circ}$ diagonal of the ROC space, the less accurate the test. (4) The slope of the tangent line at a cut point gives the likelihood ratio for that value of the test. (5) The area under the curve (AUC) is a measure of test accuracy.

You might wonder where the term receiver operating characteristic curve comes from. There is no truth to the assertion that this term was invented to confuse surgeons and to create a space for statisticians in the everyday prediction of surgical risk. ROC analysis is part of a field called signal detection theory developed during World War II for the analysis of radar images. Radar operators had to decide whether a blip on the screen represented an enemy target, a friendly ship, or just noise. Signal detection theory measures the ability of radar receiver operators to make these important distinctions. Their ability to do so was called the receiver operating characteristic. In the 1970s, signal detection theory was applied to the interpretation of medical test results and found a home. Figure 1 shows 3 ROC curves representing excellent, good, and worthless tests plotted on the same graph. The accuracy of the test depends on how well the test separates the group being tested into those 


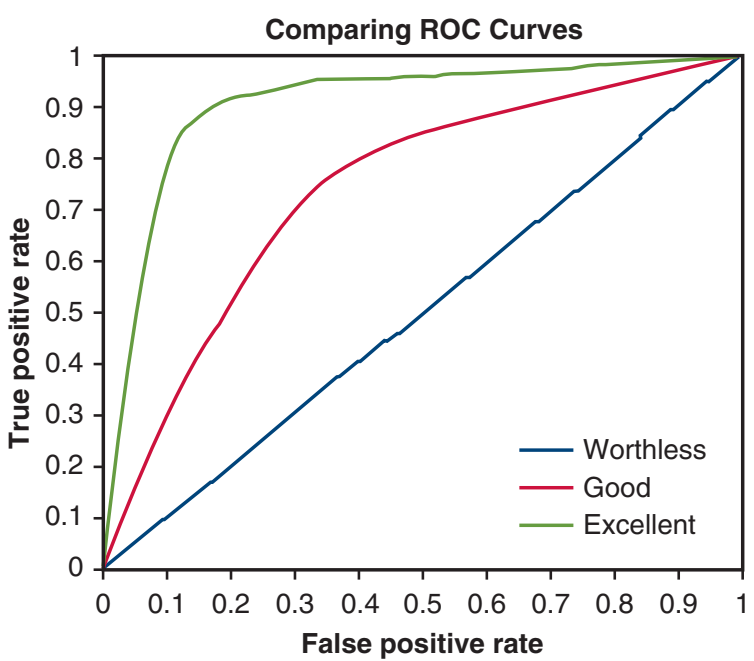

FIGURE 1. Types of receiver operating characteristic (ROC) curves.

with and without the disease in question. Accuracy is measured by the area under the ROC curve (Figure 1). An area of 1 represents a perfect test; an area of 0.5 represents a worthless test. A rough guide for classifying the accuracy of a diagnostic test is like the traditional academic point system:

- 0.90 to $1=$ excellent $(\mathrm{A})$

- 0.80 to $0.90=\operatorname{good}(\mathrm{B})$

- 0.70 to $0.80=$ fair $(\mathrm{C})$

- 0.60 to $0.70=$ poor $(\mathrm{D})$

- 0.50 to $0.60=$ fail $(\mathrm{F})$

It might be a little harsh to describe an AUC of 0.6 to 0.7 as poor, especially because many medical tests fall into this range, and investigators are proud of it.

Nonetheless, this article by Ortega-Loubon and coauthors ${ }^{1}$ leaves the reader with questions about how measurement of $\mathrm{kSO}_{2}$ can be helpful in the perioperative period. Table 1 raises some of these questions. For example, Ortega-Loubon and coauthors ${ }^{1}$ suggest that $\mathrm{kSO}_{2}$ can act as a predictor of AKI. Prediction of an event such as AKI implies that you must know a value of the predictor before the event. There are questions about how Ortega-Loubon and coauthors ${ }^{1}$ propose to use $\mathrm{kSO}_{2}$ as a predictor. Should $\mathrm{kSO}_{2}$ be measured in all patients? What should surgeons do if critical values of $\mathrm{kSO}_{2}$ occur during or after operation? Are there evidence-based interventions that might be expected to improve $\mathrm{kSO}_{2}$ levels and subsequently reduce AKI?
TABLE 1. Questions about acute kidney injury measurements during cardiopulmonary bypass

\begin{tabular}{|c|c|}
\hline Question & Relevance \\
\hline $\begin{array}{l}\text { Is } \mathrm{kSO}_{2} \text { a "predictor" } \\
\text { of } \mathrm{AKI} ?\end{array}$ & $\begin{array}{l}\text { To be a valuable predictor, it is best to } \\
\text { know the predictor value before the } \\
\text { outcome. }\end{array}$ \\
\hline $\begin{array}{l}\text { How frequently should } \\
\mathrm{kSO}_{2} \text { be measured? }\end{array}$ & $\begin{array}{l}\text { Is it practical to have real-time } \\
\text { measurements of } \mathrm{kSO}_{2} \text { ? }\end{array}$ \\
\hline $\begin{array}{l}\text { Are abnormal values } \\
\text { of } \mathrm{kSO}_{2} \text { actionable? }\end{array}$ & $\begin{array}{l}\text { Is it practical to intervene to improve } \\
\mathrm{kSO}_{2} \text { (eg, increase oxygen content, } \\
\text { transfuse, increase red cell mass, } \\
\text { etc)? }\end{array}$ \\
\hline $\begin{array}{l}\text { What factors affect } \\
\text { CSA-AKI? Are they } \\
\text { different from those } \\
\text { affecting non-cardiac } \\
\text { surgery associated AKI? }\end{array}$ & $\begin{array}{l}\text { Validation of CSA-AKI test results is } \\
\text { essential. }\end{array}$ \\
\hline $\begin{array}{l}\text { How reproducible } \\
\text { are } \mathrm{kSO}_{2} \text { measurements? }\end{array}$ & $\begin{array}{l}\text { What factors alter } \mathrm{kSO}_{2} \text { results } \\
\text { besides oxygen saturation (skin } \\
\text { pigment, obesity, etc)? }\end{array}$ \\
\hline $\begin{array}{l}\text { Are tools for measurements } \\
\text { of } \mathrm{kSO}_{2} \text { during } \mathrm{CPB} \\
\text { available? }\end{array}$ & $\begin{array}{l}\text { The authors constructed unique } \\
\text { equipment to measure } \mathrm{kSO}_{2} \text { during } \\
\mathrm{CPB} \text {. There needs to be some } \\
\text { "catch-up" in technology. }\end{array}$ \\
\hline $\begin{array}{l}\text { What interventions can } \\
\text { improve } \mathrm{kSO}_{2} \\
\text { during } \mathrm{CPB} \text { ? }\end{array}$ & $\begin{array}{l}\text { How reliable are interventions aimed } \\
\text { at improving } \mathrm{kSO}_{2} \text { (eg, increase } \\
\text { oxygen, increase perfusion } \\
\text { pressure, etc)? }\end{array}$ \\
\hline
\end{tabular}

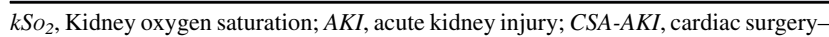
associated acute kidney injury; $C P B$, cardiopulmonary bypass.

The article is intriguing but represents a first step in a much-needed progression toward better preemptive treatment of AKI. It is easy to critique efforts of new technology, but surgeons are infused with hope for newer, safer interventions that lessen operative risk, and they are forever hopeful that cutting-edge technology can save the day and avoid one of the most dreadful and life-limiting complications of cardiac operations-renal failure. Let us hope that $\mathrm{kSO}_{2}$ measurements will provide much-needed risk assessment and possible insight into proactive treatment for AKI.

\section{Reference}

1. Ortega-Loubon C, Fernández-Molina M, Fierro I, Jorge-Monjas P, Carrascal Y Gómez-Herreras JI, et al. Postoperative kidney oxygen saturation as a novel marker for acute kidney injury after adult cardiac surgery. J Thorac Cardiovasc Surg. 2019;157:2340-51.e3. 